\title{
Leptin and Fasting Regulate Rat Gastric Glucose-Regulated Protein 58
}

\author{
Susana B. Bravo, ${ }^{1}$ Jorge E. Caminos, ${ }^{1,2,3}$ Carmen R. González, ${ }^{1,2}$ María J. Vázquez,, 2 \\ María F. Garcés, ${ }^{3}$ Libia A. Cepeda, ${ }^{3}$ María E.R. García-Rendueles, ${ }^{1}$ \\ Antonio Iglesias-Gamarra, ${ }^{3}$ Consuelo Gómez-Díaz, ${ }^{4}$ Miguel Lopez,, 2 \\ Justo P. Castaño, ${ }^{2,5}$ Carlos Diéguez, ${ }^{1,2}$ and Rubén Nogueiras ${ }^{1,2}$ \\ ${ }^{1}$ Department of Physiology, School of Medicine, Instituto de Investigaciones Sanitarias (IDIS), University of Santiago de Compostela, \\ 15782 Santiago de Compostela, Spain \\ ${ }^{2}$ CIBER Physiopathology of Obesity and Nitrition (CIBERobn), S. Francisco s/n, 15782 Santiago de Compostela, Spain \\ ${ }^{3}$ Department of Physiology and Internal Medicine, School of Medicine, National University of Colombia, 11001000 Bogota, Colombia \\ ${ }^{4}$ Central Service of Proteomic Unity for Research (SCAI), University of Cordoba, 14071 Cordoba, Spain \\ ${ }^{5}$ Department of Cell Biology, Physiology, and Immunology, University of Cordoba and Maimonides Institute of Biomedical Research \\ (IMIBIC), 14014 Cordoba, Spain
}

Correspondence should be addressed to Jorge E. Caminos, jecaminosp@unal.edu.co

and Rubén Nogueiras, ruben.nogueiras@usc.es

Received 23 June 2011; Revised 19 August 2011; Accepted 19 August 2011

Academic Editor: Jean-Marie Zajac

Copyright ( $\odot 2011$ Susana B. Bravo et al. This is an open access article distributed under the Creative Commons Attribution License, which permits unrestricted use, distribution, and reproduction in any medium, provided the original work is properly cited.

The stomach secretes a wide range of peptides with essential metabolic functions, and thereby plays an important role in the regulation of energy homeostasis. Disulfide isomerase glucose-regulated protein 58 (GRp58) is a molecular chaperone member of the endoplasmic reticulum (ER) stress signaling pathway, which is a marker for human gastric cancer. Since GRp58 seems to be regulated by a phosphorylation/dephosphorylation pattern shift, we used the 2DE gel methodology and peptide mass fingerprinting-protein identification by means of MALDI-TOF mass spectrometry. We show that gastric mucosa GRp58 is dephosphorylated by fasting, and this effect is blunted when fasted rats are treated with leptin. Furthermore, we assessed the gene expression of GRp58 under different physiological settings known to be associated with energy homeostasis (fasting, leptin treatment and leptin deficiency). We found that intraperitoneal administration of leptin increases whereas leptin deficiency decreases GRp58 mRNA levels. However, GRp58 expression remains unchanged after fasting, indicating that leptin actions on GRp58 are no direct sensitivity to fasting. Dissection of the molecular pathways mediating the interactions between ER stressrelated factors and nutrient availability, as well as their target genes, may open a new avenue for the study of obesity and other metabolic disorders.

\section{Introduction}

The stomach is a central metabolic crossroad wherein numerous signals converge and depart to control nutrient intake, appetite, and general metabolic homeostasis [1]. Thus, data gleaned over the last few years have shown that the stomach plays a key role in the regulation of food intake through the secretion of peptides such as ghrelin [2]. In addition, gastric emptying through the regulation of gastric distension also influence the rate of intestinal exposure of nutrients thereby influencing the secretion of a vast array of gastrointestinal hormones which in turn also control food intake and/or energy expenditure. Therefore, the stomach has emerged as a key organ in the regulation of body weight homeostasis, and gastric surgery is at the front line of treatment of patients with morbid obesity. However, there is a general lack of knowledge on the adaptation process that take part in the stomach in relation to energy balance. We felt 
the critical question pending was to identify the subcellular events that take place in this tissue and its relationship to alterations in energy balance.

Disulfide isomerase glucose-regulated protein 58 (also known as, GRp58, ERp57, ER-60, ERp60, ERp61) is a molecular chaperone member of the ER-stress signaling pathway. Specifically, GRp58 is a $58 \mathrm{kDa}$ thiol-disulfide oxidoreductase protein, physiologically involved in the folding catalysts modification of disulfide bonds in glycoprotein [3,4], and has been previously identified in the stomach as a marker for human gastric cancer [5]. Moreover, it is also highly expressed in liver, placenta, and lung, and weakly expressed in other tissues [4]. In vitro and in vivo studies have shown that GRp58 protein acts on glycosylated substrates through the ER resident lectins-calnexin and the calreticulin system to catalyze the isomerization or exchange of disulfide bonds $[6,7]$. GRp58 substrates share common properties: they are glycoprotein, heavily disulfide bonded, and likely to form nonnative disulfide bonds $[6,7]$. Most of these substrates contain abundant domains of cysteine residues, which usually promote formation of the disulfide bonds during glycoprotein folding [6-8]. In line with the interrelation among metabolism, ER-stress and chaperone function, it has been shown that GRp58 expression is induced by different stress conditions, such as glucose deprivation or hypoxia $[9,10]$. Furthermore, hepatic GRp58 was phosphorylated after 12-h/24-h fasting and after leptin treatment [11], and interacts with the JAK-STAT signaling pathway implicated in the intracellular signal transduction of leptin [12].

Although GRp58 is a marker for human gastric cancer [5], few studies have addressed the regulation and potential role of ER-stress, and in particular that of GRp58, in gastric function. We aimed to investigate the involvement of GRp58 in energy homeostasis. Our results demonstrate that GRp58 is expressed in rat gastric and reveal that gastric GRp58 mRNA expression and dephosphorylation are increased after leptin treatment. Therefore, our results suggest that gastric GRp58 might play an important role in the regulation of energy homeostasis.

\section{Methods and Procedures}

2.1. Animals. Adult male Sprague Dawley rats (250-300 g, $8-10$ weeks old) were bred in the animalario General USC; University of Santiago de Compostela, Spain, and male leptin-deficient mice (8 weeks old) were purchased from Charles River, Barcelona, Spain. Animals were housed in open cages under conditions of controlled illumination (12hour light/dark schedule), humidity, and temperature. The animals were sacrificed by decapitation in a room separate from other experimental animals in the afternoon (16:0017:00 h). The gastric mucosa was then collected and frozen at $-80^{\circ} \mathrm{C}$ until analysis. All experiments were conducted in accordance with the European Union Laws on protection regarding laboratory animals after previous approval by the Ethics Committee of the University of Santiago de Compostela, Spain (Permit number: PGIDIT06PXIB208063PR).
2.1.1. Experimental Setting 1: Effects of Fasting. Animal groups ( $n=8$ per group) were deprived of food for $48 \mathrm{~h}$ while the control group was fed ad libitum [13]. All animals had free access to tap water. Gastric mucosa was rapidly dissected and stored at $-80^{\circ} \mathrm{C}$ until proteomic and mRNA analyses were performed.

\subsubsection{Experimental Setting 2: Effects of Leptin Treatment and} Leptin Deficiency. We next investigated whether leptin affects gastric mucosa GRp58 mRNA expression and modifications in the protein phosphorylation pattern shift. Rats and mice were assigned to one of the following groups $(n=8$ per group): (a) i.p. vehicle fed ad libitum; (b) i.p. leptin fed ad libitum; (c) i.p. vehicle after $48 \mathrm{~h}$ fasting and (d) i.p. leptin after $48 \mathrm{~h}$ fasting. On the other hand, leptin-deficient animals were distributed in three groups: (a) i.p. vehicle fed ad libitum, (b) i.p. vehicle after 48h-fasting and (c) i.p. leptin after $48 \mathrm{~h}$ fasting. Animals were treated with recombinant leptin (L-4146, Sigma-Aldrich) at a dose of $0.8 \mu \mathrm{g} / \mathrm{kg}$ of body weight every $12 \mathrm{~h}$ for 3 days (intraperitoneal injection) as described elsewhere [13].

For the proteomic setting, we treated rats with leptin at short term: $6 \mathrm{~h}$ and $24 \mathrm{~h}$ before the sacrifice with a single intraperitoneal injection $(0,8 \mu \mathrm{g} / \mathrm{kg}$ of body weight in a volume of $0.25 \mathrm{~mL})$. We again had the same 4 groups $(n=4$ per group). The reason we carried out this short-term experiment for proteomic approaches is that the pattern shift of phosphorylation/dephosphorylation is commonly faster than changes at transcriptional level.

2.2. Western Blot Analysis. Western blot analysis from $1 \mathrm{D}$ and 2D gels were performed as described elsewhere [14]. Briefly, gastric mucosa proteins were resolved by polyacrylamide gel electrophoresis according to the method described below and transferred to nitrocellulose membrane (Hybond CSuper, Amersham Pharmacia Biotech). Membranes were incubated with primary antibodies against Erp57 (H-220; sc-28823. Santa Cruz Biotechnology, Santa Cruz, CA, USA) and alpha-tubulin (Sigma; Poole, UK). The membranes after incubation with respective secondary antibodies were probed with HRP-conjugated secondary antibodies and the signal was developed with chemiluminescence reagents (Tropix, Bedford; MA, USA) and exposed to X-ray film. All the experiments were repeated four times and a representative result is shown.

2.3. Two-Dimensional Electrophoresis. 2DE analyses were performed using four samples per group. Gastric mucosa was lysed at $4^{\circ} \mathrm{C}$ using a tissue homogenizator (Omni TissueMaster-125 Homogenizers). Lysates were prepared in lysis buffer ( $7 \mathrm{M}$ urea, $2 \mathrm{M}$ thiourea, $4 \%$ CHAPS, $5 \mathrm{mM}$ magnesium acetate, $20 \mathrm{mMTris} \mathrm{HCl} \mathrm{pH}$ 8.5, 0.2\% ampholytes $\mathrm{w} / \mathrm{v}$, and bromophenol trace). Samples were centrifuged at $15000 \mathrm{~g}$ under $4^{\circ} \mathrm{C}$ during $15 \mathrm{~min}$ to remove the debris as described previously [15].

First dimension isoelectric focusing was performed with the horizontal Multiphor IPGphor III system (GE Healthcare, formerly Amersham Biosciences); using $11 \mathrm{~cm}$ IPG 
strips (pH 4-7, GE Healthcare). The sample $(50 \mu \mathrm{g})$ was dissolved by soaking in $200 \mu \mathrm{L}$ of rehydration buffer (7M Urea, $2 \mathrm{M}$ thiourea, 4\% CHAPS and bromophenol trace) during 8 hours. Then, it was loaded onto an $11 \mathrm{~cm}$-linear range with $\mathrm{pH} 4-7$ immobilized gradient strip (4 gels per experimental group and each one originated from different animals) and isoelectric focusing was performed as recommended by the manufacturer, ramping the voltage subsequently applied to reach 6000 Vht. The strips containing focused proteins were thawed, equilibrated, and reduced in equilibration buffer $(6 \mathrm{M}$ urea, $50 \mathrm{mM} \mathrm{M}$ Tris- $\mathrm{Cl} \mathrm{pH}$ $8.8,2 \%$ SDS, $30 \%$ glycerol, and $2 \%(\mathrm{w} / \mathrm{v})$ DTT) during $15 \mathrm{~min}$, then alkylated in equilibration buffer $(6 \mathrm{M}$ urea, $50 \mathrm{mM}$ Tris-Cl pH 8.8, 30\% glycerol, 2\% SDS, 2.5\% (w/v) iodoacetamide. Equilibrated strips were transferred to a SDSPAGE gel (10\%), secured in place by molten agarose and subjected to electrophoresis (Mini-Protean Tetra Cell; Bio-Rad Laboratories). Afterwards, electrophoresis gels were stained using PlusOne Silver Staining Kit, Protein (GE Healthcare), as recommended by the manufacturer protocols.

2.4. MALDI-TOF/TOF Mass Spectrometry and Protein Identification. Spots were excised automatically in a ProPic station (Genomic Solutions, UK) and digested with modified porcine trypsin (sequencing grade; Promega), by using a ProGest digestion station (Genomic Solutions, U.K.). The gel specimens were destained twice over $30 \mathrm{~min}$ at $37 \circ \mathrm{C}$ with $200 \mathrm{mM}$ ammonium bicarbonate $/ 40 \%$ acetonitrile. Gel pieces were then subjected to three consecutive dehydratation/rehydratation cycles with pure acetonitrile and $25 \mathrm{mM}$ ammonium bicarbonate in 50\% acetonitrile, respectively, and finally dehydrated for $5 \mathrm{~min}$ with pure acetonitrile and dried out over $4 \mathrm{~h}$ at room temperature. Then, $20 \mu \mathrm{L}$ trypsin, at a concentration of $12.5 \mathrm{ng} / \mu \mathrm{L}$ in $25 \mathrm{mM}$ ammonium bicarbonate was added to the dry gel pieces and the digestion proceded at $37 \circ \mathrm{C}$ for $12 \mathrm{~h}$. Peptides were extracted from gel plugs by adding $1 \mu \mathrm{L}$ of $10 \%$ (v/v) trifluoracetic acid (TFA) and incubating for $15 \mathrm{~min}$. Then, they were desalted and concentrated by using $\mu \mathrm{C}-18$ ZipTip columns (Millipore) in a ProMS station (Genomic Solutions, U.K.) and directly loaded onto the MALDI plate using $\alpha$-cyano hydroxycinnamic acid as the matrix.

Mass analysis of peptides of each sample were performed with a MALDI-TOF/TOF (4700 Proteomics Analyzer, Applied Biosystems, USA) in automatic mode with the following setting: for the MS data, $\mathrm{m} / \mathrm{z}$ range 800 to 4000 with an accelerating voltage of $20 \mathrm{kV}$ and delayed extraction, peak density of maximum 50 peaks per $200 \mathrm{Da}$, minimal S/N ratio of 10 and maximum peak at 65 . Spectra were internally calibrated with peptides from trypsin autolysis $(\mathrm{M}+\mathrm{H}+=$ 842.509, M + H+ =2211.104).

For the MS/MS data, mass range was set between $60 \mathrm{Da}$ and 10 Da below each precursor mass, with a minimum S/N ratio of 5 , a maximum number of peak set at 65 and peak density of maximum 50 peaks per $200 \mathrm{Da}$. Proteins were assigned identification by peptide mass fingerprinting and confirmed by MS/MS analysis. Mascot 2.0 search engine (Matrix Science, U.K.) was used for protein identification running on GPS software (Applied Biosystems) over the National Center for Biotechnology Information (NCBI) protein database (updated monthly).

Search setting allowed one missed cleavage with the selected trypsin enzyme, an MS/MS fragment tolerance of $0.2 \mathrm{Da}$ and a precursor mass tolerance of $100 \mathrm{ppm}$. Proteins with a statistically significant $(P<0.05)$ were positively assigned identification after considering $\mathrm{Mr}$ and $\mathrm{pI}$ values.

\subsection{RNA Isolation and GRp58 mRNA Expression Analysis} by RT-PCR. Total RNA from gastric mucosa was extracted using Trizol (Invitrogen, Inc.) according to the manufacturer's instructions. RNA was reverse transcribed and the resulting cDNA was synthesized from 2 ug total RNA by random priming RT. The resulting cDNA was subjected to PCR amplification as described at $[13,16]$ using sense and antisense primers specific for the rat GRp58 and the housekeeping gene hypoxanthine guanine phosphoribosyltransferase (HPRT) mRNAs (Table 1).

2.6. Real-Time Semiquantitative RT-PCR. For real-time semiquantitative analysis we used the Applied Biosystems 7500 Real-Time PCR System (Applied Biosystems, CA, USA), as previously described [13-15]. Rat GRp58 and 18S ribosomal rRNA relative gene expression quantification was made using specific primers and TaqMan fluorescent probes for these target genes, and the sequences are described in Table 1.

2.7. Statistical Analysis. The results are shown as the means \pm SEM (standard error of the mean) and analyzed by using GraphPad Instat 3.05 (GraphPad Software, Inc.) software. Statistical significance was determined by Student's $t$-test when two groups were compared. In the experiments constituted by three groups the data were analyzed by oneway ANOVA followed by a post hoc multiple comparison test (Bonferroni test). $P<0.05$ was considered significant.

\section{Results}

3.1. Rat Gastric GRp58 mRNA Expression. Expression of the mRNA encoding GRp58 gene (Figure 1) was evaluated by RT-PCR and compared to housekeeping gene HPRT. This analysis demonstrates the expression of the message of the gene in male rat liver and gastric mucosa whereas its expression was not found in tissues such as pancreas and brain (Figure 1).

3.2. Rat Gastric GRp58 Protein Levels. After discovering that GRp58 is expressed in the gastric mucosa by means of RT-PCR, we employed Western blot analysis to determine whether the message is translated into protein. Using a specific primary antibody for GRp58, we detected a major band in protein extracts of rat gastric, and observed that protein levels of GRp58 were decreased after $24 \mathrm{~h}$ and $48 \mathrm{~h}$ of fasting (Figure 2). Moreover, in the gastric mucosa of rats fasted during $48 \mathrm{~h}$, we found that the band had a lower molecular weight, likely suggesting a dephosphorylation (Figure 2). 
TABLE 1: PCR primers and probe sequence for rat GRp58 and 18S ribosomal rRNA.

\begin{tabular}{lll}
\hline Primer/probe & Sequence & Genebank accession number \\
\hline GRP58FW & $5^{\prime}$-GGACCAGCTTCAGTTCCTCTCA-3' & \\
GRP58RV & $5^{\prime}$-TGCTGGCTGCTTTTAGGAACTC-3' & NM_017319.1 \\
GRP58Pb & FAM 5'-ATGCCTCGGTGGTGGGCTTTTTCA- 3'TAMRA & \\
\hline 18 SFW & $5^{\prime}$-CGGCTACCACATCCAAGGAA-3' & M11188.1 \\
18 SRV & $5^{\prime}$-GCTGGAATTACCGCGGCT-3' & \\
18 SPb & FAM 5'-GACGGCAAGTCTGGTGCCAGCA-3'TAMRA & NM_012583 \\
HPRT FW & $5^{\prime}$-CAGTCCCAGCGTCGTGATTA-3' & \\
HPRT RV & $5^{\prime}$-AGCAAGTCTTTCAGTCCTGTC-3' & \\
\hline
\end{tabular}

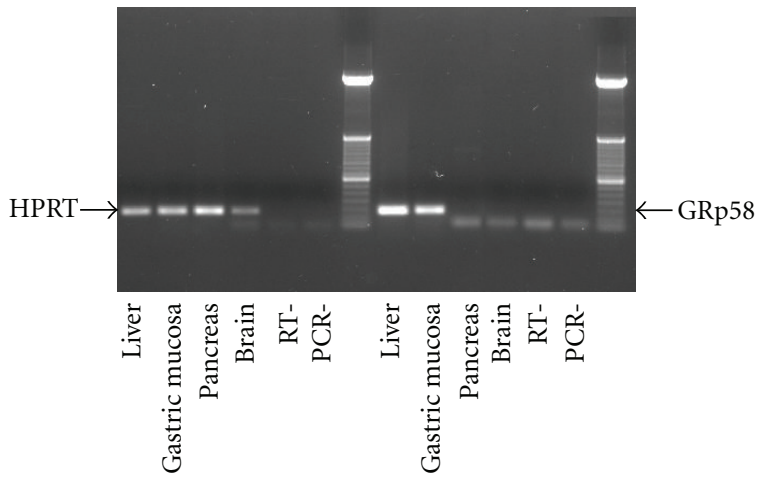

FIGURE 1: Expression of GRp58 gene in rat gastric. Representative RT-PCR assay of the expression levels of GRp58 mRNA in liver and gastric mucosa whereas pancreas and brain failed to show any amplification. HPRT was used as a housekeeping gene.

3.3. Proteomic Identification and Molecular Analysis. To test the hypothesis that GRp58 was dephosphorylated during fasting, we performed proteomic analysis. Representative 2DE gel images of rat gastric tissue with differential expressed protein in fed state (Figure 3(a)) compared to fasted state (Figure 3(b)). Differentially expressed protein spots (marked with letters) were picked, digested with trypsin, and analyzed by peptide mass fingerprinting as previously described (Tables 2 and 3) [17, 18]. The peptide mass fingerprints were acquired by mass spectrometry using a matrix-assisted laser desorption/ionization time-of-flight (MALDI-TOF). All analyzed spots correspond to multiple phosphorylated forms of GRp58 protein, which were identified by the comparison of peptide mass fingerprint data generated by MALDI-TOF mass spectrometry against theoretically digested Homo sapiens, Swiss-Prot and TrEMBL database, and by the use of Mascot software. Among the identified protein spots, a 4-protein series with identical molecular weight of approximately $58 \mathrm{kDa}$ and different isoelectric points were identified as GRp58. These differences reflect different degrees of phosphorylation as previously described [19-21]. The identified phosphorylated forms of GRp58 protein in rat gastric along with referred data are listed in Table 3. These phosphorylation profile shifts were identified through a 2-DE Western blot analysis using an anti-GRp58 antibody,
TABLE 2: Cutoff score value for protein: 71 (score is $-10 * \log (P)$, where $P$ is the probability that the observed match is a random event. Protein scores greater than 71 are significant $(P<0.05))$. The software used for peak-picking was 4000 Series Explorer (TM) RAC Software, version 3.5.3 (Applied Biosystems/MDS SCIEX, Concord, Ontario, Canada). Parameters and thresholds used for peak-picking: (a) intensity or $\mathrm{S} / \mathrm{N}$ threshold: $\mathrm{S} / \mathrm{N}=10$, local noise window width $(\mathrm{m} / \mathrm{z})=250$, min peak width at full width half $\max$ (bins) $=2.9$; (b) means of calibrating each spectrum: internal calibration with peptides from trypsin autolysis $\left(\mathrm{M}+\mathrm{H}^{+}=842.509\right.$, $\mathrm{M}+\mathrm{H}^{+}=2211.104$ ); (c) resolution: 12000 for the mass 842.51 and 18000 for the mass 2211. Search parameters: (a) MASCOT (Matrix Science, London, UK) software, VERSION 2.0; (b) enzyme specificity: trypsin; (c) missed cleavages permitted: 1; (d) fixed modification (s): carbamidomethyl (C); (e) variable modifications: oxidation (M), Phospho (ST), Phospho (Y); (f) mass tolerance for precursor ions: $\pm 100 \mathrm{ppm}$; (g) mass tolerance for fragment ions: $\pm 0.2 \mathrm{Da}$; (h) name of database searched and release version: NCBInr 20080628 (6655203 sequences); (i) species restriction: Mammalia (mammals) (689751 sequences); (j) acceptance criteria: cut-off score value for protein: 71 (score is $-10 * \log (P)$, where $P$ is the probability that the observed match is a random event. Protein scores greater than 71 are significant $(P<0.05))$.

\begin{tabular}{lcccc}
\hline Spot No & $\begin{array}{c}\text { protein } \\
\text { score }\end{array}$ & $\begin{array}{c}\text { protein } \\
\text { score 1\% }\end{array}$ & $\begin{array}{c}\text { Coverage } \\
\%\end{array}$ & $\begin{array}{c}\text { Number of } \\
\text { peptides } \\
\text { identified }\end{array}$ \\
\hline P1 $^{\prime}$ & 170 & 100 & 60 & 13 \\
P2 $^{\prime}$ & 149 & 100 & 50 & 12 \\
P1 & 282 & 100 & 90 & 24 \\
P2 & 439 & 100 & 95 & 24 \\
P3 & 288 & 100 & 64 & 15 \\
P4 & 237 & 100 & 55 & 12 \\
\hline
\end{tabular}

recognizing four immunoreactive protein spots (Figures 4(a) and $4(b))$ that showed a basic shifted signal in the profile of GRp58.

3.4. Fasting Induces GRp58 Dephosphorylation Whereas Leptin Blunts Fasting-Induced Dephosphorylation of Gastric Mucosa GRp58. Additionally, using 2DE, we found that $48 \mathrm{~h}$ of fasting dephosphorylated gastric mucosa GRp58 in comparison with rats fed ad libitum (Figure 5). When $48 \mathrm{~h}$ fasted-rats were treated with leptin for 6 hours or $24 \mathrm{~h}$, we 
TABLE 3: Identification of GRp58 protein in the gastric mucosa of the rat. Rat gastric proteins were separated by 2-DE and identified by means of MALDI-TOF. The protein identified represents the spots shown in Figures 1(a) and 1(b): protein disulfide-isomerase A3 precursor (Disulfide isomerase ER-60; ERp60; $58 \mathrm{kDa}$ microsomal protein; p58; ERp57; HIP-70; Q-2; 35 petides), the spots labelled as P1' and P2' are the same spots as P1 and P2 but in different gels.

\begin{tabular}{|c|c|c|c|c|c|c|}
\hline \multirow[b]{2}{*}{ Observed Mr (expt) } & \multicolumn{3}{|c|}{ Protein MW: 57043.9} & Protein PI: 5.88 & \multicolumn{2}{|l|}{ Accession No: gi|1352384| } \\
\hline & $\operatorname{Mr}($ calc $)$ & $\pm \mathrm{da}$ & $\pm \mathrm{ppm}$ & Start-end & Sequence & Spot number \\
\hline 823.4785 & 823.4559 & 0.0226 & 27 & 190-196 & IVAYTEK & $\mathrm{p} 1^{\prime}, \mathrm{p} 1$ \\
\hline 866.4574 & 866.4617 & -0.0043 & 5 & $387-393$ & YKELGEK & $\mathrm{p} 1^{\prime}, \mathrm{p} 1$ \\
\hline 877.4915 & 877.489275 & 0.0025 & 3 & $268-275$ & LNFAVASR & $\mathrm{p} 1^{\prime}, \mathrm{p} 1$ \\
\hline 995.5628 & 995.5632 & -0.0004 & 0 & $102-111$ & QAGPASVPLR & $\mathrm{p} 1^{\prime}, \mathrm{p} 1$ \\
\hline 997.5101 & 997.459 & -0.0511 & -51 & $153-161$ & DASVVGFFR & $\mathrm{p} 2$ \\
\hline 1084.5674 & 1084.5688 & 0.0014 & 1 & $95-104$ & YGVSGYPTLK & $\mathrm{p} 2^{\prime}, \mathrm{p} 1, \mathrm{p} 2, \mathrm{P} 3$ \\
\hline 1123.6582 & 1123.6589 & 0.0007 & 1 & $101-111$ & KQAGPASVPLR & $\mathrm{p} 1^{\prime}, \mathrm{p} 1$ \\
\hline 1125.547 & 1125.5436 & 0.0034 & 3 & $243-251$ & NTKGSNYWR & $\mathrm{p} 1$ \\
\hline 1172.5404 & 1172.4702 & -0.0702 & -60 & $336-344$ & FVMQEEFSR & $\mathrm{p} 1, \mathrm{p} 2$ \\
\hline 1179.5865 & 1179.6239 & 0.0374 & 32 & $174-183$ & AASNLRDNYR & $\mathrm{p} 2^{\prime}, \mathrm{p} 1, \mathrm{p} 2$ \\
\hline 1188.5354 & 1188.5305 & -0.0049 & -4 & $344-336$ & FVMQEEFSR & $\mathrm{p} 2^{\prime}, \mathrm{p} 1, \mathrm{p} 2, \mathrm{P} 3$ \\
\hline 1191.6005 & 1191.6084 & 0.0079 & 7 & $63-73$ & LAPEYEAAATR & $\mathrm{p} 1^{\prime}, \mathrm{p} 2^{\prime}, \mathrm{p} 1, \mathrm{p} 2, \mathrm{P} 3, \mathrm{P} 4$ \\
\hline 1236.5127 & 1236.5029 & -0.0098 & -8 & $108-119$ & DGEEAGAYDGPR & $\mathrm{p} 2^{\prime}, \mathrm{p} 1, \mathrm{p} 2, \mathrm{P} 3$ \\
\hline 1244.6633 & 1244.6276 & -0.0357 & -29 & $184-194$ & FAHTNVESLVK & $\mathrm{p} 1, \mathrm{P} 3$ \\
\hline 1341.6837 & 1341.683 & -0.0007 & -1 & $449-460$ & GFPTIYFSPANK & $\mathrm{p} 2^{\prime}, \mathrm{p} 1, \mathrm{p} 2, \mathrm{P} 3, \mathrm{P} 4$ \\
\hline 1347.7043 & 1347.7015 & 0.0028 & 2 & $33-44$ & RLAPEYEAAATR & $\mathrm{p} 1$ \\
\hline 1373.6736 & 1373.5839 & -0.0897 & -65 & $352-362$ & FLQEYFDGNLK & $\mathrm{p} 2$ \\
\hline 1394.6587 & 1394.5729 & -0.0858 & -62 & $162-173$ & DLFSDGHSEFLK & $\mathrm{p} 1, \mathrm{p} 2$ \\
\hline 1396.6954 & 1396.6727 & -0.0227 & -16 & $367-379$ & SEPIPETNEGPVK & $\mathrm{p} 2^{\prime}, \mathrm{p} 1, \mathrm{p} 2, \mathrm{P} 3, \mathrm{P} 4$ \\
\hline 1397.5784 & 1397.7063 & 0.1279 & 92 & $83-94$ & VDCTANTNTCNK & $\mathrm{p} 1^{\prime}, \mathrm{p} 2^{\prime}, \mathrm{p} 2, \mathrm{P} 3, \mathrm{P} 4$ \\
\hline 1397.7059 & 1397.7063 & 0.0004 & 0 & $472-482$ & ELNDFISYLQR & $\mathrm{p} 1^{\prime}, \mathrm{p} 2^{\prime}, \mathrm{p} 1, \mathrm{P} 3, \mathrm{P} 4$ \\
\hline 1469.7787 & 1469.691 & -0.0877 & -60 & $449-461$ & GFPTIYFSPANKK & $\mathrm{p} 1, \mathrm{p} 2, \mathrm{P} 4$ \\
\hline 1472.6838 & 1472.6184 & -0.0654 & -44 & $336-347$ & FVMQEEFSRDGK & $\mathrm{p} 2$ \\
\hline 1488.6787 & 1488.6698 & -0.0089 & -6 & $336-347$ & FVMQEEFSRDGK & P3 \\
\hline 1529.7747 & 1529.775 & 0.0003 & 0 & $352-363$ & FLQEYFDGNLKR & $\mathrm{p} 1^{\prime}, \mathrm{p} 2^{\prime}, \mathrm{p} 1, \mathrm{p} 2, \mathrm{P} 3, \mathrm{P} 4$ \\
\hline 1593.8483 & 1593.8551 & 0.0068 & 4 & $483-496$ & EATNPPIIQEEKPK & $\mathrm{p} 2^{\prime}, \mathrm{p} 1, \mathrm{p} 2, \mathrm{P} 3, \mathrm{P} 4$ \\
\hline 1607.7476 & 1607.764 & 0.0164 & 10 & $259-271$ & DLLTAYYDVDYEK & $\mathrm{p} 1^{\prime}, \mathrm{p} 2^{\prime}, \mathrm{p} 2, \mathrm{P} 3, \mathrm{P} 4$ \\
\hline 1636.7523 & 1636.6552 & -0.0971 & -59 & $434-448$ & MDATANDVPSPYEVK & $\mathrm{p} 1, \mathrm{p} 2, \mathrm{P} 4$ \\
\hline 1652.7472 & 1652.6615 & -0.0857 & -52 & $434-448$ & MDATANDVPSPYEVK & $\mathrm{p} 2$ \\
\hline 1652.7662 & 1652.7704 & 0.0042 & 3 & $105-119$ & IFRDGEEAGAYDGPR & $\mathrm{p} 1^{\prime}, \mathrm{p} 2^{\prime}, \mathrm{p} 1, \mathrm{p} 2, \mathrm{P} 3, \mathrm{P} 4$ \\
\hline 1744.8864 & 1744.7698 & -0.1166 & -67 & $131-146$ & QAGPASVPLRTEDEFK & p2 \\
\hline 1746.9286 & 1746.8311 & -0.0975 & -56 & 289-304 & TFLDAGHKLNFAVASR & $\mathrm{p} 1^{\prime}$ \\
\hline 1800.9377 & 1800.9132 & -0.0245 & -14 & $364-379$ & YLKSEPIPETNEGPVK & $\mathrm{p} 1^{\prime}, \mathrm{p} 2^{\prime}, \mathrm{p} 1, \mathrm{p} 2, \mathrm{P} 3, \mathrm{P} 4$ \\
\hline 1950.9331 & 1950.7816 & -0.1515 & -78 & $259-274$ & DLLTAYYDVDYEKNTK & $\mathrm{p} 2$ \\
\hline 2463.1279 & 2462.9673 & -0.1606 & -65 & $83-104$ & VDCTANTNTCNKYGVSGYPTLK & $\mathrm{p} 2$ \\
\hline
\end{tabular}

observed that the fasting-induced GRp58 dephosphorylation was blunted (Figure 5). Therefore, our results indicate that the dephosphorylation of gastric mucosa GRp58 induced by fasting, a hypoleptinemic state, is likely mediated by circulating leptin levels.

3.5. Gastric Mucosa GRp58 mRNA Levels Are Induced by Leptin. We then measured the mRNA expression of gastric mucosa GRp58 in the same experimental paradigm described above, meaning, fed ad libitum, fasted, and fasted leptin-treated rats. We failed to detect any significant change in the gene expression of GRp58 of fasted rats when compared to feed ad libitum rats (Figure 6(a)). However, we found that leptin treatment was able to trigger gastric mucosa GRp58 mRNA levels in fasted rats in comparison with vehicle-treated rats (Figure 6(a)). Similar results were detected in fed ad libitum rats, which showed a clear upregulation in GRp58 gene expression after the leptin treatment (Figure 6(b)). According to pharmacological data, the endogenous lack of leptin downregulated gastric mucosa 


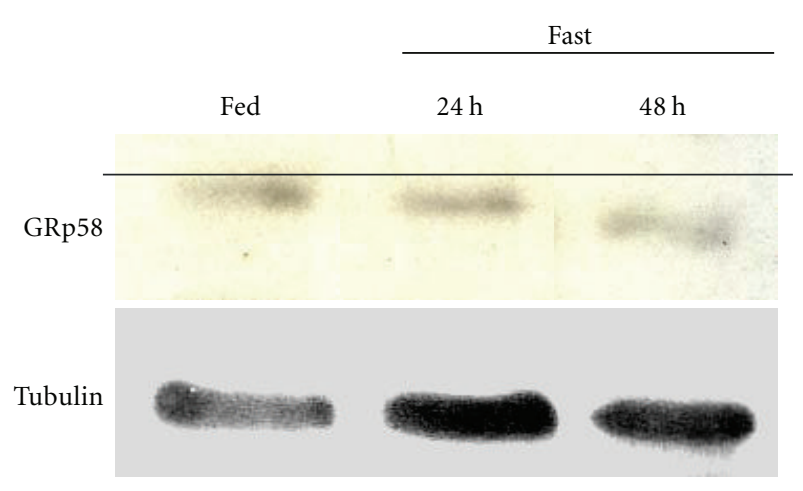

(a)

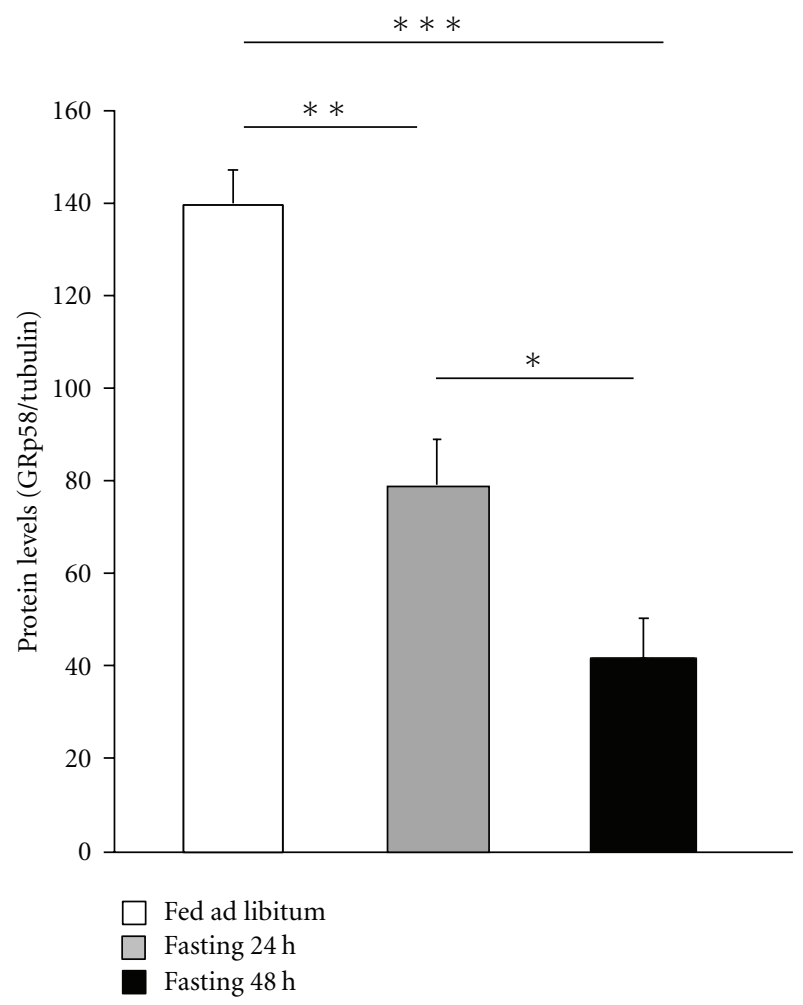

(b)

Figure 2: Representative Western blot analysis (a) and quantification (b) of rat gastric GRp58 protein levels in fasted rats. Fifty micrograms of total proteins were loaded on a $10 \%$ SDS-PAGE gel. To confirm equal loading, the same blot was stripped off and incubated with monoclonal beta-tubulin antibody. Values are mean \pm SEM of 8 rats per group.

GRp58 gene expression when compared to wild-type mice (Figure 6(c)). Finally, when leptin-deficient mice were fasted for $48 \mathrm{~h}$ we failed to detect changes in GRp58 mRNA levels, but when those fasted mice were treated with exogenous leptin, an increase in gastric mucosa GRp58 gene expression was found (Figure 6(d)). Overall, our findings show that leptin is an important mediator of GRp58 gene expression in the gastric mucosa.

\section{Discussion}

The endoplasmic reticulum (ER) is a multifunctional organelle that plays a critical role in multiple cellular processes including, among others, protein and lipid biosynthesis, steroid production, calcium homeostasis, and carbohydrate metabolism [6]. In addition, the ER contains a large number of calcium-dependent molecular chaperones and folding enzymes, which are physiologically responsible for several cotranslational and posttranslational modifications [22, 23]. Alterations in energy metabolism including glucose/energy deprivation, oxidative injury, hypoglycemia, hypoxia, and high-fat diet impair ER homeostasis. More specifically, nutritional excess induces ER stress in subcutaneous adipose tissue of obese human subjects [24]. Additionally, ER stress has been related to the development of atherosclerosis and diabetes [24-27]. For instance, obese humans and rodents develop ER stress in liver and adipose tissues, leading to insulin resistance whereas weight-loss decreases ER stress and improves insulin sensitivity, suggesting a correlation between ER stress and the metabolic syndrome [27, 28].

By using proteomics analysis, we found evidence of a GRp58 phosphorylation/dephosphorylation pattern shift in the rat gastric under changes in nutritional status. More specifically, using the 2DE gel methodology and peptide mass fingerprinting-protein identification by means of MALDITOF mass spectrometry, we show that gastric mucosa GRp58 is dephosphorylated by fasting, and this effect is blunted when fasted rats are treated with leptin. GRp58, a wellknown stress protein, has been previously identified in the stomach as a marker for human gastric cancer [5]. Furthermore, previous works have demonstrated the presence of leptin and leptin receptor in the stomach, suggesting that gastric mucosa cells may be targets for leptin [29, 30]. GRp58 and signal transducer and activator of transcription 3 (STAT3), an essential signaling molecule mediating the biological actions of leptin [31], have been localized in both the cytoplasm and nucleus [32, 33]. In this regard, some studies have shown that GRp58 may be implicated in the transcriptional control of STAT3 [12, 32]. Notwithstanding the evidence mentioned above, there was a general lack of knowledge regarding a potential role of gastric GRp58 in metabolism. Concurring with a role of gastric GRp58 on energy balance, we demonstrate that leptin induces, whereas leptin-deficiency reduces, gastric mucosa GRp58 mRNA expression, suggesting that leptin modulates both GRp58 phosphorylation and expression. Since these effects seem to be nutritional, it is plausible to hypothesize that other tissues that are target of leptin action in nutritional context like the intestine might be also involved in the regulation of GRp58. For instance, leptin is expressed and secreted by inflamed colonic epithelial cells [34], it may act as a growth factor in colon tissue [35]. Moreover, leptin receptors have been located in the rat colonic epithelium [36]. Thus, the role of leptin on GRp58 throughout the entire gastrointestinal tract deserves further investigation.

Our findings obtained in rat gastric differ from data obtained in the rat liver, where it was found that serine 150 of GRp58 was phosphorylated by both fasting and leptin 


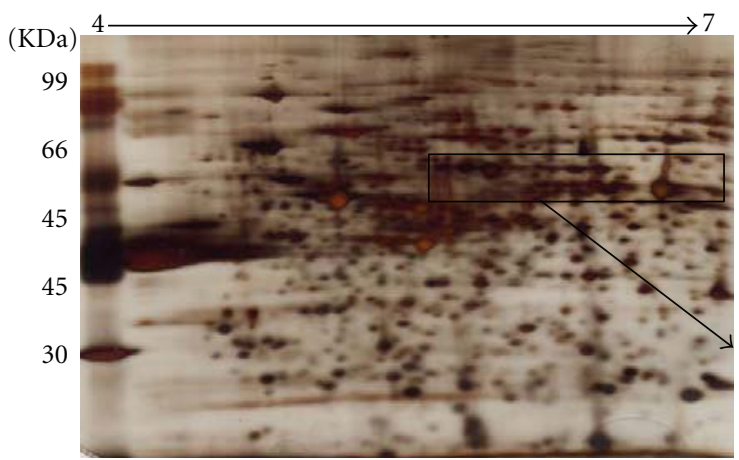

Rat gastric mucosa

fed ad libitum

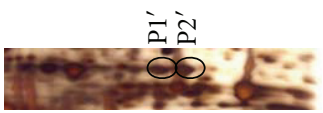

(a)

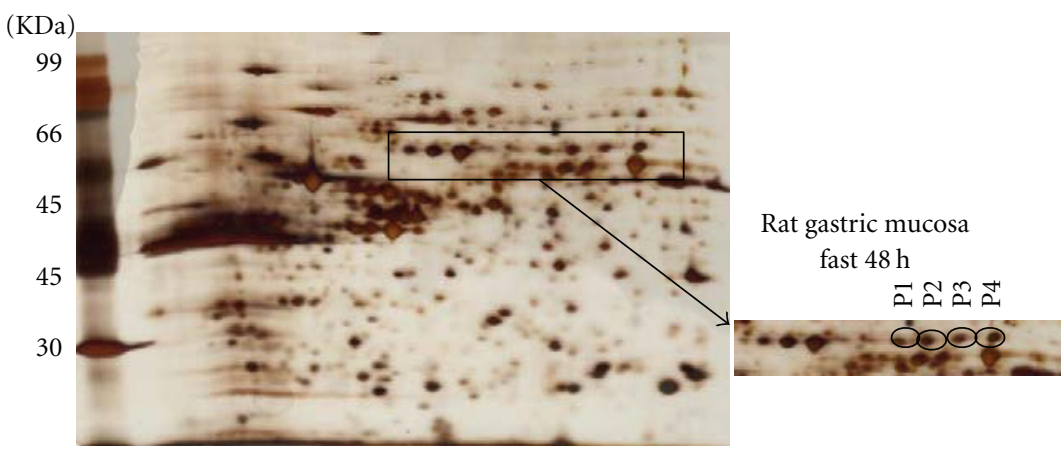

(b)

FIGURE 3: Representative 2-DE gel image of gastric mucosa proteins from fed ad libitum (a) and $48 \mathrm{~h}$ fasted (b) rats. Gastric proteins were extracted from mucosa and separated on an immobilized $\mathrm{pH} 4-7$ nonlinear gradient strip followed by separation on a $12 \%$ polyacrylamide gel. Silver stained gel and spots differentially expressed proteins in fed controls relative to fasted rats were picked, and analysis by mass spectrometry allowed the detection and identification of different GRp58 phosphorylated forms. Values are mean \pm SEM of 8 rats per group.

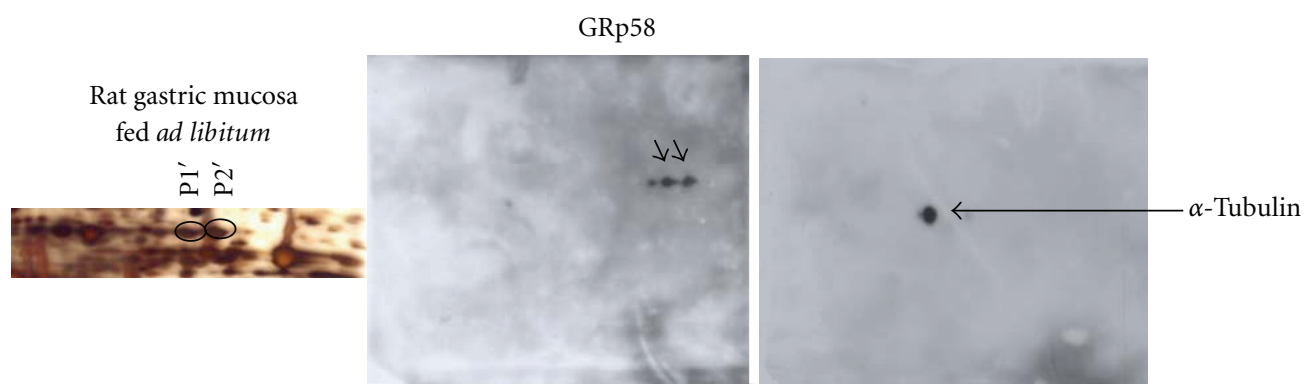

(a)

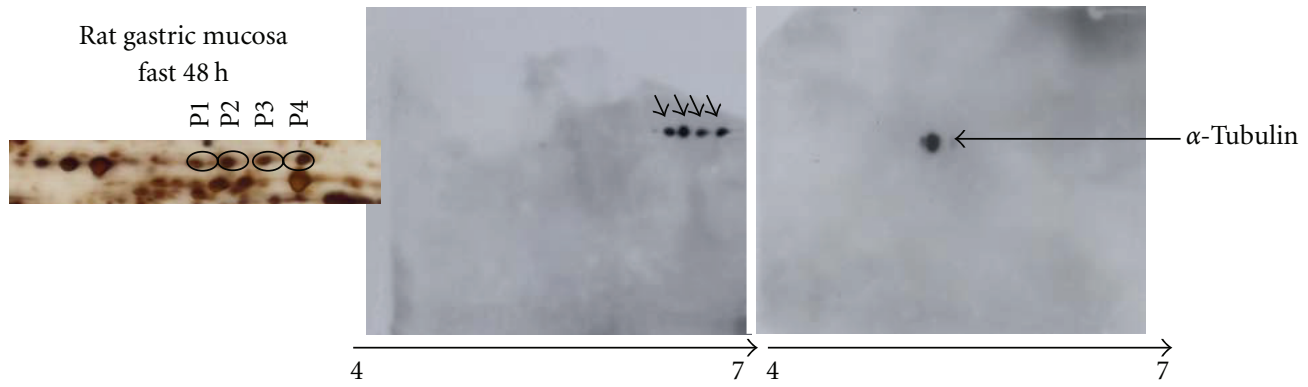

(b)

Figure 4: 2DE gel electrophoretic analysis and immunoblot image of gastric mucosa proteins from fed (a) and $48 \mathrm{~h}$ fasted (b) rats. Image shows the position of GRp58 phosphorylated forms and alpha-tubulin detected by incubation with anti-GRp58, and anti alpha-tublin, respectively. The position of GRp58 phosphorylated forms and alpha-tubulin in the silver-stained and nitrocellulose $2 \mathrm{D}$ is indicated by arrows. 


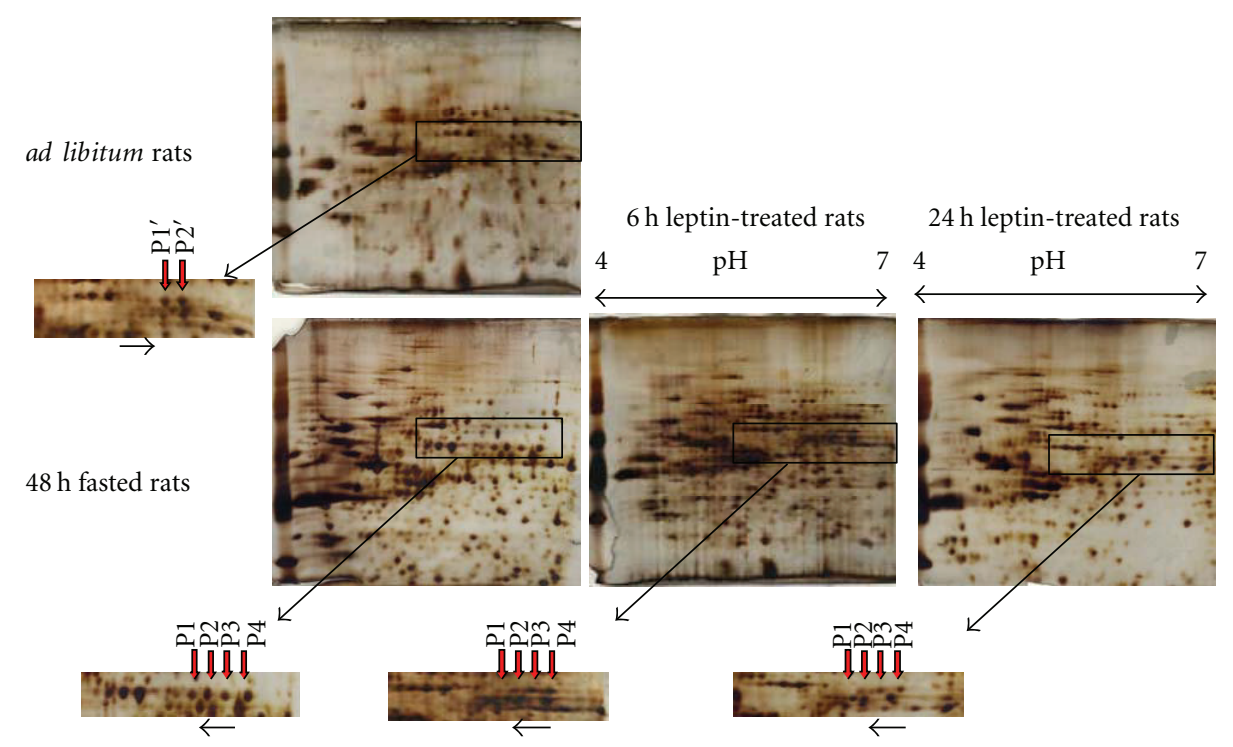

FIGURE 5: 2-DE gel image of GRp58 phosphorylation pattern of rat gastric from fed, $48 \mathrm{~h}$ fasted rats, and $48 \mathrm{~h}$ fasted rats treated with leptin and sacrificed after $6 \mathrm{~h}$ and $24 \mathrm{~h}$ of leptin administration. GRp58 protein acidic isoelectric points decreased in 2DE gels in fasted and leptin treated rats compared to vehicle-treated control fed rats. Gastric mucosa proteins were extracted and separated on an immobilized pH 47 non-linear gradient strip followed by separation on a $12 \%$ polyacrylamide gel. Red arrows show the different phosphorilation pattern observed in different treatments.

[11]. Thereby, those results were indicating that nutritionalinduced changes in liver GRp58 phosphorylation were not mediated by circulating leptin levels. Our current data demonstrating that leptin blocks the fasting-induced dephosphorylation of gastric GRp58 suggest that changes in the activity of this protein are modulated by nutritional status. Importantly, leptin seems to be responsible for those nutritional-induced changes in gastric GRp58 phosphorylation. Moreover, the different results obtained in the pattern of GRp58 phosphorylation in the liver [11] and the stomach suggests that GRp58 is regulated by nutritional status in a tissue-specific manner. Since we have detected multiple phosphorylated forms of GRp58 protein in the gastric mucosa (Figure 2), we hypothesize that these phosphorylated forms could contribute to the tissue-specific regulation of GRp58 in response to fasting and leptin treatment.

It is important to point out several issues that deserve further attention. First, the functional role of phosphorylation/dephosphorylation of GRp58 caused by physiological and physiopathological conditions is largely unknown. Second, the sites of phosphorylation/dephosphorylation of Grp58 are different in each tissue [11,37], so it might be possible that the GRp58 phosphorylated forms that we detected in the gastric mucosa also have different phosphorylation sites. Third, the factors that induce these phosphorylation/dephosphorylation shifts in a tissue-specific manner are mostly unknown. All these issues seem relevant to elucidate the precise role and mechanisms mediating GRp58 actions in the organism.

In addition to the actions of nutritional status on the pattern of gastric mucosa GRp58 phosphorylation, we have also assessed the regulation of GRp58 gene expression. Our findings indicate that leptin increases GRp58 mRNA expression whereas leptin deficiency decreases the levels of this protein. Since leptin lowers blood glucose levels and leptin-deficient mice are hyperglycemic, our results are in agreement with previous in vitro results indicating that GRp58 expression is induced by glucose deprivation [38].

Although GRp58 mRNA expression remained unchanged after fasting, we found that its protein levels were decreased after $24 \mathrm{~h}$ and $48 \mathrm{~h}$ of fasting. These results suggest that fasting modulates GRp58 at post-transcriptional levels. Therefore, it is likely that the actions of leptin on GRp58 are dependent of nutritional status. On the other hand, the ingestion of specific components of the diet like fructose increases the secretion of gastric leptin [39], and this might also affect GRp58 gastric levels.

Taken together, our findings obtained on the dephosphorylation and total mRNA expression of GRp58 indicate that leptin regulates the phosphorylation and expression of gastric GRp58 in rats. It also seems reasonable to hypothesize that at least some of the actions of leptin at the gastric level might be mediated by GRp58 [40].

In conclusion, our results demonstrate that GRp58 phosphorylation responds rapidly to changes in dietary energy and leptin treatment, and thereby support that GRp58 can play an important physiological role in the signaling pathways related to energy balance in the stomach. More precisely, our findings indicate that (a) fasting dephosphorylates gastric mucosa GRp58, (b) leptin blunts fasting-induced GRp58 dephosphorylation, and (c) leptin stimulates gastric mucosa mRNA expression. Dissection of the molecular pathways mediating the interactions between ER stress-related factors and nutrient availability, as well as their target genes may open a new avenue for the study of obesity and other metabolic disorders. 


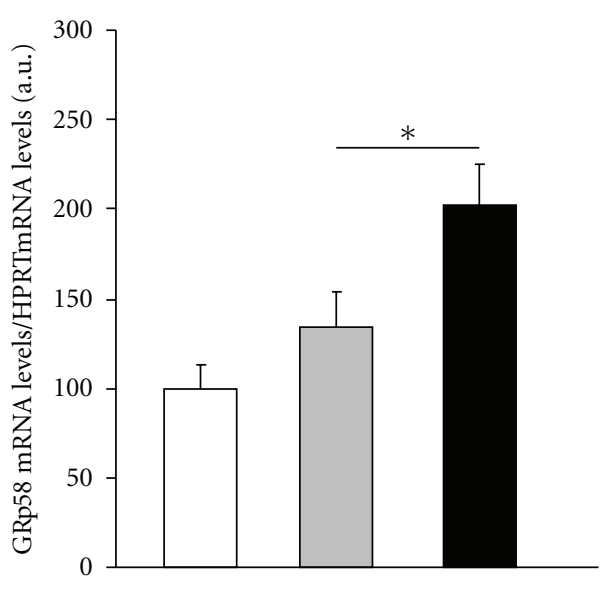

Fed ad libitum + vehicle

Fasting $48 \mathrm{~h}+$ vehicle

Fasting $48 \mathrm{~h}+$ leptin

(a)

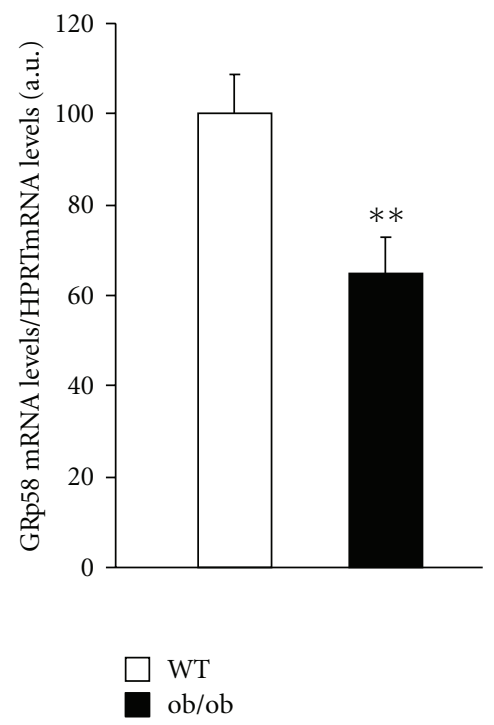

(c)

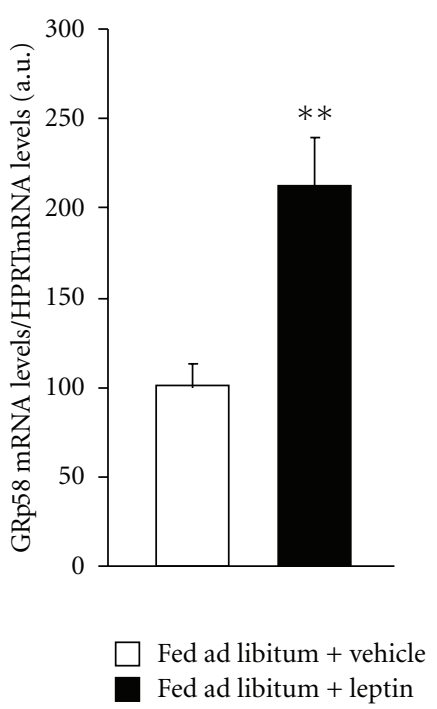

(b)

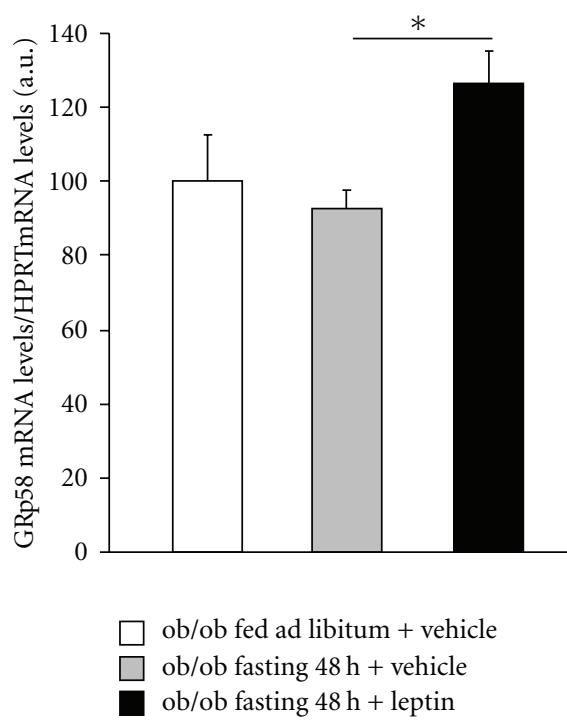

(d)

Figure 6: Gastric mucosa GRp58 mRNA levels in fed, 48 h fasted rats, and 48 h fasted rats treated with leptin (a). Gastric mucosa GRp58 mRNA levels in fed versus leptin-treated rats (b). Gastric mucosa GRp58 mRNA levels in wild-type mice versus leptin-deficient mice (ob/ob) (c). Gastric mucosa GRp58 mRNA levels in ob/ob mice fed ad libitum, fasted for $48 \mathrm{~h}$, and fasted for $48 \mathrm{~h}$ treated with leptin (d). $n=8$ per group. Gastric mucosa GRp58/18S were measured using RT-real time PCR. Mean \pm SEM are reported. ${ }^{*} P<0.05,{ }^{* *} P<0.01$.

\section{Conflict of Interests}

The authors declare no conflict of interest.

\section{Acknowledgments}

All authors have substantially contributed to conception, design, and interpretation of the data. All authors have revised the paper critically and gave final approval of the version to be published. This work has been supported by grants of the National Direction of Investigations (DIB) and the Vicerrectory of Research of the Universidad Nacional de Colombia, Spanish Ministry of Science and Innovation (CD: BFU2008;
RN: RYC-2008-02219 and SAF2009-07049, JPC: BFU201019300), Xunta de Galicia (CD: PGIDIT06PXIB208063PR; RN: 2010/14), and European Union (CD: Health-F2-2008223713: "Reprobesity"). CIBER de Fisiopatología de la Obesidad y Nutrición is an initiative of ISCIII, Madrid, Spain. (J.P.C: Junta de Andalucía BIO-0139/CTS-5051).

\section{References}

[1] J. Cegla, T. M. Tan, and S. R. Bloom, "Gut-brain cross-talk in appetite regulation," Current Opinion in Clinical Nutrition and Metabolic Care, vol. 13, no. 5, pp. 588-593, 2010. 
[2] M. Kojima, H. Hosoda, Y. Date, M. Nakazato, H. Matsuo, and K. Kangawa, "Ghrelin is a growth-hormone-releasing acylated peptide from stomach," Nature, vol. 402, no. 6762, pp. 656660, 1999.

[3] M. Michalak, J. Groenendyk, E. Szabo, L. I. Gold, and M. Opas, "Calreticulin, a multi-process calcium-buffering chaperone of the endoplasmic reticulum," Biochemical Journal, vol. 417, no. 3, pp. 651-666, 2009.

[4] P. Koivunen, N. Horelli-Kuitunen, T. Helaakoski et al., "Structures of the human gene for the protein disulfide isomeraserelated polypeptide ERp60 and a processed gene and assignment of these genes to 15q15 and 1q21," Genomics, vol. 42, no. 3, pp. 397-404, 1997.

[5] C. M. Leys, S. Nomura, B. J. LaFleur et al., "Expression and prognostic significance of prothymosin- $\alpha$ and ERp57 in human gastric cancer," Surgery, vol. 141, no. 1, pp. 41-50, 2007.

[6] F. Hatahet and L. W. Ruddock, "Substrate recognition by the protein disulfide isomerases," FEBS Journal, vol. 274, no. 20, pp. 5223-5234, 2007.

[7] L. Ellgaard and L. W. Ruddock, "The human protein disulphide isomerase family: substrate interactions and functional properties," EMBO Reports, vol. 6, no. 1, pp. 28-32, 2005.

[8] P. Maattanen, G. Kozlov, K. Gehring, and D. Y. Thomas, "ERp57 and PDI: multifunctional protein disulfide isomerases with similar domain architectures but differing substratepartner associations," Biochemistry and Cell Biology, vol. 84, no. 6, pp. 881-889, 2006.

[9] L. Cicchihitti, M. Di Michele, A. Urbani et al., "Comparative proteomic analysis of paclitaxel sensitive A2780 epithelial ovarian cancer cell line and its resistant counterpart A2780TC1 by 2D-DIGE: the role of ERp57," Journal of Proteome Research, vol. 8, no. 4, pp. 1902-1912, 2009.

[10] S. Laudi, W. Steudel, K. Jonscher et al., "Comparison of lung proteome profiles in two rodent models of pulmonary arterial hypertension," Proteomics, vol. 7, no. 14, pp. 2469-2478, 2007.

[11] K. Kita, N. Okumura, T. Takao et al., "Evidence for phosphorylation of rat liver glucose-regulated protein 58, GRP58/ERp57/ER-60, induced by fasting and leptin,” FEBS Letters, vol. 580, no. 1, pp. 199-205, 2006.

[12] G. G. Guo, K. Patel, V. Kumar et al., "Association of the chaperone glucose-regulated protein 58 (GRP58/ER-60/ERp57) with Stat 3 in cytosol and plasma membrane complexes," Journal of Interferon and Cytokine Research, vol. 22, no. 5, pp. 555-563, 2002.

[13] C. R. Gonzalez, M. J. Vazquez, M. Lopez, and C. Dieguez, "Influence of chronic undernutrition and leptin on GOAT mRNA levels in rat stomach mucosa," Journal of Molecular Endocrinology, vol. 41, no. 6, pp. 415-421, 2008.

[14] J. E. Caminos, S. B. Bravo, M. E. Garcia-Rendueles et al., "Expression of neuropeptide $\mathrm{W}$ in rat stomach mucosa: regulation by nutritional status, glucocorticoids and thyroid hormones," Regulatory Peptides, vol. 146, no. 1-3, pp. 106-111, 2008.

[15] A. Paradela, S. B. Bravo, M. Henriquez, G. Riquelme, F. Gavilanes, and J. P. Albar, "Proteomic analysis of apical microvillous membranes of syncytiotrophoblast cells reveals a high degree of similarity with lipid rafts," Journal of Proteome Research, vol. 4, no. 6, pp. 2435-2441, 2005.

[16] C. R. Gonzalez, J. E. Caminos, R. Gallego et al., "Adiponectin receptor 2 is regulated by nutritional status, leptin and pregnancy in a tissue-specific manner," Physiology and Behavior, vol. 99, no. 1, pp. 91-99, 2010.
[17] V. Goeb, M. Thomas-L'Otellier, R. Daveau et al., "Candidate autoantigens identified by mass spectrometry in early rheumatoid arthritis are chaperones and citrullinated glycolytic enzymes," Arthritis Research and Therapy, vol. 11, no. 2, article R38, 2009.

[18] T. C. Lai, H. C. Chou, Y. W. Chen et al., "Secretomic and proteomic analysis of potential breast cancer markers by twodimensional differential gel electrophoresis," Journal of Proteome Research, vol. 9, no. 3, pp. 1302-1322, 2010.

[19] Y. Tokutomi, N. Araki, K. Kataoka, E. Yamamoto, and S. Kim-Mitsuyama, "Oxidation of Prx2 and phosphorylation of GRP58 by angiotensin II in human coronary smooth muscle cells identified by 2D-DIGE analysis," Biochemical and Biophysical Research Communications, vol. 364, no. 4, pp. 822830, 2007.

[20] M. Obeid, "ERP57 membrane translocation dictates the immunogenicity of tumor cell death by controlling the membrane translocation of calreticulin," Journal of Immunology, vol. 181, no. 4, pp. 2533-2543, 2008.

[21] T. Panaretakis, N. Joza, N. Modjtahedi et al., "The co-translocation of ERp57 and calreticulin determines the immunogenicity of cell death," Cell Death and Differentiation, vol. 15, no. 9, pp. 1499-1509, 2008.

[22] J. Mandl, T. Meszaros, G. Banhegyi, L. Hunyady, and M. Csala, "Endoplasmic reticulum: nutrient sensor in physiology and pathology," Trends in Endocrinology and Metabolism, vol. 20, no. 4, pp. 194-201, 2009.

[23] A. R. English, N. Zurek, and G. K. Voeltz, "Peripheral ER structure and function," Current Opinion in Cell Biology, vol. 21, no. 4, pp. 596-602, 2009.

[24] G. Boden, X. Duan, C. Homko et al., "Increase in endoplasmic reticulum stress-related proteins and genes in adipose tissue of obese, insulin-resistant individuals," Diabetes, vol. 57, no. 9, pp. 2438-2444, 2008.

[25] N. Naidoo, "ER and aging-Protein folding and the ER stress response," Ageing Research Reviews, vol. 8, no. 3, pp. 150-159, 2009.

[26] S. G. Fonseca, M. Burcin, J. Gromada, and F. Urano, "Endoplasmic reticulum stress in $\beta$-cells and development of diabetes," Current Opinion in Pharmacology, vol. 9, no. 6, pp. 763770, 2009.

[27] M. F. Gregor, L. Yang, E. Fabbrini et al., "Endoplasmic reticulum stress is reduced in tissues of obese subjects after weight loss," Diabetes, vol. 58, no. 3, pp. 693-700, 2009.

[28] G. S. Hotamisligil, "Endoplasmic reticulum stress and the inflammatory basis of metabolic disease," Cell, vol. 140, no. 6, pp. 900-917, 2010.

[29] A. Bado, S. Levasseur, S. Attoub et al., "The stomach is a source of leptin," Nature, vol. 394, no. 6695, pp. 790-793, 1998.

[30] I. Sobhani, A. Bado, C. Vissuzaine et al., "Leptin secretion and leptin receptor in the human stomach," Gut, vol. 47, no. 2, pp. 178-183, 2000.

[31] E. C. Villanueva and M. G. Myers Jr., "Leptin receptor signaling and the regulation of mammalian physiology," International Journal of Obesity, vol. 32, supplement 7, pp. S8S12, 2008.

[32] M. I. Ndubuisi, G. G. Guo, V. A. Fried, J. D. Etlinger, and P. B. Sehgal, "Cellular physiology of STAT3: where's the cytoplasmic monomer?" Journal of Biological Chemistry, vol. 274, no. 36, pp. 25499-25509, 1999.

[33] M. Eufemi, S. Coppari, F. Altieri, C. Grillo, A. Ferraro, and C. Turano, "ERp57 is present in STAT3-DNA complexes," Biochemical and Biophysical Research Communications, vol. 323, no. 4, pp. 1306-1312, 2004. 
[34] N. K. Saxena, M. A. Titus, X. Ding et al., "Leptin as a novel profibrogenic cytokine in hepatic stellate cells: mitogenesis and inhibition of apoptosis mediated by extracellular regulated kinase (Erk) and Akt phosphorylation," FASEB Journal, vol. 18, no. 13, pp. 1612-1614, 2004.

[35] T. Aparicio, L. Kotelevets, A. Tsocas et al., "Leptin stimulates the proliferation of human colon cancer cells in vitro but does not promote the growth of colon cancer xenografts in nude mice or intestinal tumorigenesis in $A p c^{\mathrm{Min} /+}$ mice," Gut, vol. 54, no. 8, pp. 1136-1145, 2005.

[36] J. E. Drew, A. J. Farquharson, S. Padidar et al., "Insulin, leptin, and adiponectin receptors in colon: regulation relative to differing body adiposity independent of diet and in response to dimethylhydrazine," American Journal of Physiology, vol. 293, no. 4, pp. G682-G691, 2007.

[37] A. Donella-Deana, P. James, W. Staudenmann et al., "Isolation from spleen of a $57-\mathrm{kDa}$ protein substrate of the tyrosine kinase Lyn: identification as a protein related to protein disulfide-isomerase and localisation of the phosphorylation sites," European Journal of Biochemistry, vol. 235, no. 1-2, pp. 18-25, 1996.

[38] M. Flores-Diaz, J. C. Higuita, I. Florin et al., "A cellular UDPglucose deficiency causes overexpression of glucose/oxygenregulated proteins independent of the endoplasmic reticulum stress elements," Journal of Biological Chemistry, vol. 279, no. 21, pp. 21724-21731, 2004.

[39] M. H. Vickers, Z. E. Clayton, C. Yap, and D. M. Sloboda, "Maternal fructose intake during pregnancy and lactation alters placental growth and leads to sex-specific changes in fetal and neonatal endocrine function," Endocrinology, vol. 152, no. 4, pp. 1378-1387, 2011.

[40] S. Guilmeau, M. Buyse, and A. Bado, "Gastric leptin: a new manager of gastrointestinal function," Current Opinion in Pharmacology, vol. 4, no. 6, pp. 561-566, 2004. 

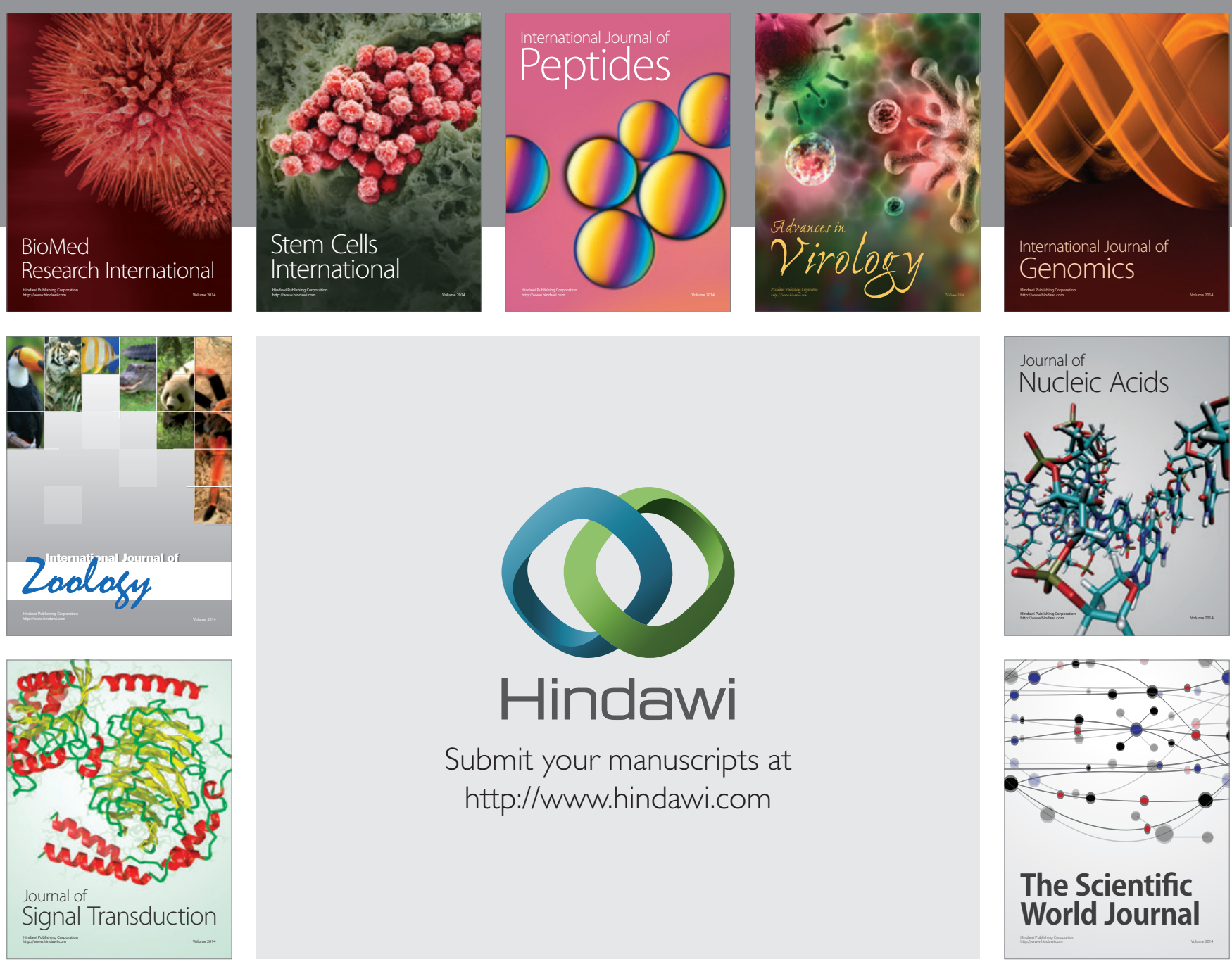

Submit your manuscripts at

http://www.hindawi.com
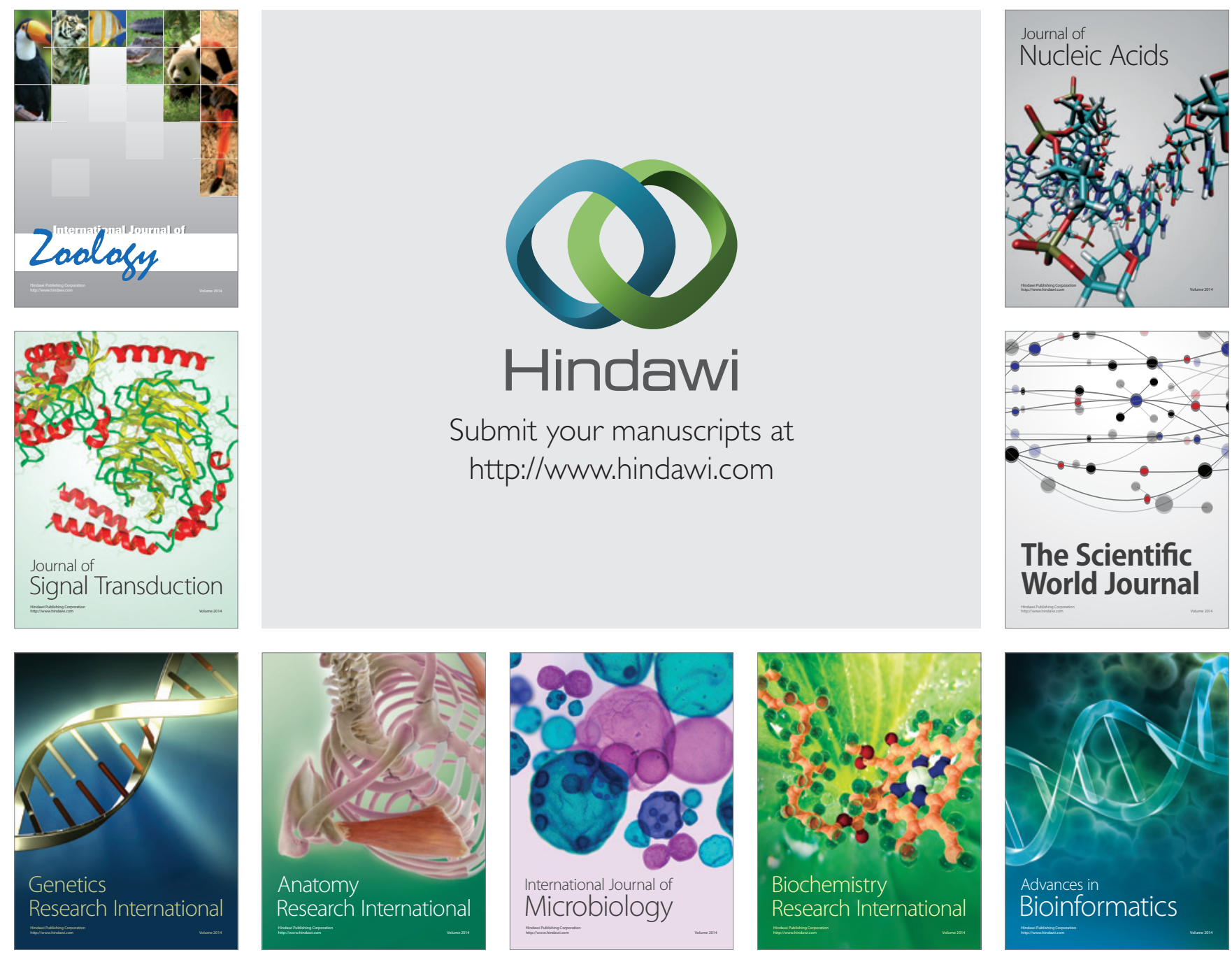

The Scientific World Journal
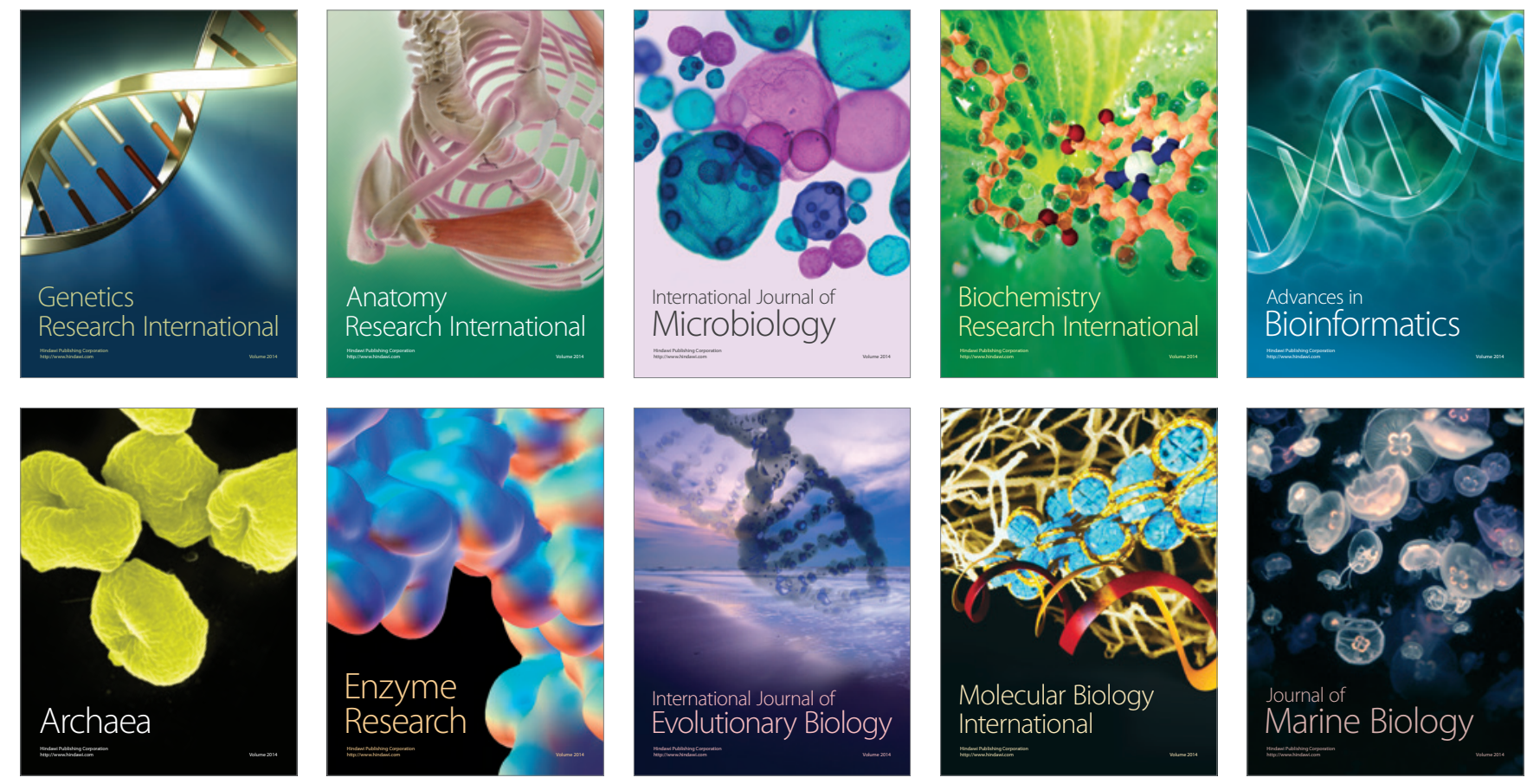